\title{
Retroflection of part of the east Greenland current at Cape Farewell
}

\author{
N. Penny Holliday, ${ }^{1}$ Amélie Meyer, ${ }^{1}$ Sheldon Bacon, ${ }^{1}$ Steven G. Alderson, ${ }^{1}$ \\ and Beverly de Cuevas ${ }^{1}$
}

Received 13 December 2006; revised 13 March 2007; accepted 15 March 2007; published 14 April 2007.

[1] The east Greenland current (EGC) and the smaller east Greenland coastal current (EGCC) provide the major conduit for cold fresh polar water to enter the lower latitudes of the North Atlantic. They flow equatorward through the western Irminger Basin and around Cape Farewell into the Labrador Sea. The surface circulation and transport of the Cape Farewell boundary current region in summer 2005 is described. The EGCC merges with Arctic waters of the EGC to the south of Cape Farewell, forming the west Greenland current. The EGC transport decreases from 15.5 Sv south of Cape Farewell to $11.7 \mathrm{~Sv}$ in the eastern Labrador Sea (where the water becomes known as Irminger Sea Water). The decrease in EGC transport is balanced by the retroflection of a substantial proportion of the boundary current $(5.1 \mathrm{~Sv})$ into the central Irminger Basin; a new pathway for fresh water into the interior of the subpolar gyre. Citation: Holliday, N. P., A. Meyer, S. Bacon, S. G. Alderson, and B. de Cuevas (2007), Retroflection of part of the east Greenland current at Cape Farewell, Geophys. Res. Lett., 34, L07609, doi:10.1029/2006GL029085.

\section{Introduction}

[2] The east Greenland current (EGC) (along with the smaller east Greenland coastal current or EGCC) are often cited as being the major conduits for cold fresh polar water to enter the lower latitudes of the North Atlantic [e.g., Hansen and Østerhus, 2000; Bacon et al., 2002; Pickart et al., 2005]. The EGC is a complex current that exchanges water with the Arctic, the Nordic Seas and the subpolar North Atlantic along its pathway from the Fram Strait to Cape Farewell at the southernmost point of Greenland [Rudels et al., 2002]. Thus the properties and transport vary greatly all along its pathway. To the east of Cape Farewell the EGC consists of surface-to-intermediate cold fresh Arctic-origin waters from north of the Denmark Strait $\left(\theta \sim 3.0-6.0^{\circ} \mathrm{C}, \mathrm{S}<34.95\right)$, surface-to-intermediate warm saline Atlantic-origin water from the Irminger current $(\theta \sim$ $\left.6.0-9.0^{\circ} \mathrm{C}, \mathrm{S} \sim 34.95-35.05\right)$ [Holliday et al., 2006], with cold dense overflow water at depth. Despite numerous hydrographic surveys of the EGC there are few direct velocity measurements and hence few absolute transport estimates of the EGC. A survey in 1997 [Lherminier et al., 2007] resulted in an EGC transport east of Cape Farewell shallower than $\sigma_{0}=27.7$ of $15.5 \mathrm{~Sv}$; a survey in 2001 [Pickart et al., 2005] reported a total transport of $13.6 \mathrm{~Sv}$ in the EGC through the Irminger Basin; but historical esti-

\footnotetext{
${ }^{1}$ National Oceanography Centre, Southampton, University of Southampton, Southampton, UK.
}

Copyright 2007 by the American Geophysical Union. 0094-8276/07/2006GL029085\$05.00 mates range from 2 to $35 \mathrm{~Sv}$ at various points along the current pathway (see Pickart et al. [2005] for a comprehensive review). Two recent surveys of the EGCC east of Cape Farewell put its transport at $1.0 \mathrm{~Sv}$ [Bacon et al., 2002] and $2.0 \mathrm{~Sv}$ [Pickart et al., 2005] and a re-analysis of historical data shows the baroclinic component of the EGCC varied between 0.5 and $2.0 \mathrm{~Sv}$ between 1932 and 1997 [Wilkinson and Bacon, 2005].

[3] After the boundary current turns the corner at Cape Farewell it becomes known as the Irminger Sea Water (ISW) inflow of the Labrador Sea, transporting an estimated $11 \mathrm{~Sv}$ of warm saline water $\left(\theta \sim 4.5^{\circ} \mathrm{C}, \mathrm{S} \sim 34.95\right)$ [Clarke, 1984; Cuny et al., 2002]. Inshore of that flow is the cold fresh water of the west Greenland current $\left(\theta \sim-1.8^{\circ} \mathrm{C}, \mathrm{S} \leq\right.$ 34.5) which has been observed as transporting $3 \mathrm{~Sv}$ [Clarke, 1984].

[4] Despite investigations going back as far as 1933, the boundary current system around Cape Farewell still retains some mystery. It is not clear how the currents to the east of Cape Farewell relate to the currents to its west, though it is generally assumed that the latter are a continuation of the former. The EGC is characterised by changing properties all along its pathway, but until now the mixing and modification of water types at Cape Farewell have not been described. Most transport estimates are snapshots, and it is still not clear how representative they might be, given that the EGC is partially wind-driven and partially thermohaline. Historical surveys suggest the baroclinic transport of the EGC increases downstream, but before now no observations of the absolute surface transport around Cape Farewell have been made.

[5] In this study we will discuss the synoptic surface circulation and transport of the Cape Farewell boundary current region. We calculate new absolute total transport estimates for the EGC, provide evidence that the EGCC merges with the EGC south of Cape Farewell, and describe a significant decrease in EGC transport as it rounds the Cape and flows into the Labrador Sea. We demonstrate that the decrease in EGC transport is balanced by the retroflection of a substantial proportion of the boundary current into the central Irminger Basin, describing a new pathway for fresh water into the interior of the subpolar gyre.

\section{Data and Methods}

\subsection{Survey}

[6] In August and September 2005 RRS Discovery cruise 298 [Bacon, 2006] completed a CTD (Conductivity-Temperature-Depth) and ADCP (Acoustic Doppler Current Profiler) survey around Cape Farewell, the southernmost part of Greenland. At each station a SeaBird 911 plus CTD was lowered in a frame that contained $24,10 \mathrm{~L}$ water sampling bottles and two Lowered ADCPs (RDI Workhorse 


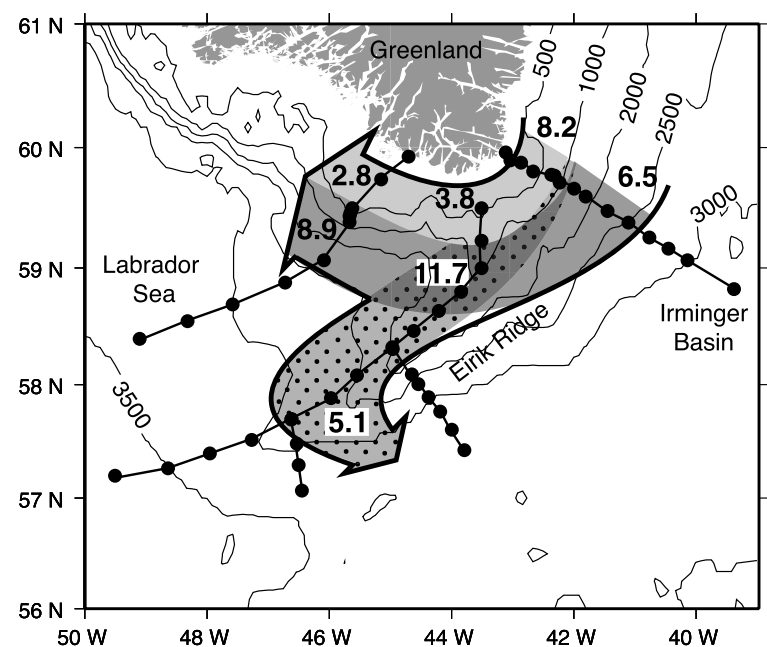

Figure 1. Schematic of the circulation and partial retroflection of the east Greenland current (EGC) and east Greenland coastal current (EGCC) around Cape Farewell. The solid circles and thin black lines show the CTD positions and cruise track of D298 in August-September 2005. The broad arrow shows the general pathway of the western boundary current system. The pale grey shading indicates the cold fresh EGCC and Arctic-origin EGC water and its associated transport. The dark grey shading indicates the warm saline Atlantic-origin EGC and its transport. The dotted-grey shading indicates the new water type formed by mixing in the deepest part of the EGC between the Irminger Basin and the Eirik Ridge. Note that it spreads from beneath the EGC along the Eirik Ridge, decreasing in depth as it does so. Total transport values for each section have a measurement error of approximately $\pm 1 \mathrm{~Sv}$.

$300 \mathrm{kHz}$, one upward and one downward looking). Calibrated CTD sensor accuracies were $1 \mathrm{dbar}$ (pressure), $1 \mathrm{~m}^{\circ} \mathrm{C}$ (temperature) and 0.001 (salinity). Data from a Shipboard RDI $150 \mathrm{kHz}$ Broadband ADCP (SADCP) were used to calculate underway absolute water velocities. The survey consisted of three main sections from the coast to the deep ocean (Figure 1): one section in the southern Irminger Basin; another section running down the crest of Eirik Ridge, a bathymetric feature which extends southwestwards from Cape Farewell; and one section in the southern Labrador Sea. The Eirik Ridge section included two short CTD sections normal to the Ridge, designed to survey the deep overflow plume.

\subsection{Using ADCP Data to Obtain Absolute Velocities}

[7] Absolute transports between station pairs were calculated by referencing geostrophic (baroclinic) shear with current velocities from ADCPs (to add the barotropic component). The method is fully described by E. L. McDonagh et al. (The circulation of the Indian Ocean at $32^{\circ} \mathrm{S}$, submitted to Progress in Oceanography, 2007) and is summarised as follows. The data from the LADCPs were processed using the Lamont Doherty Earth Observatory LADCP Software Version 7b Dec 2002 [Visbeck, 2002] using GPS navigation data and bottom-tracked velocities to obtain absolute onstation velocities. SADCP data provided an independent check for the LADCP velocities. Individual LADCP profiles were rejected as suspect data if they had differences of $>5 \mathrm{~cm} \mathrm{~s}^{-1}$ between up and down casts in the $u$ or $v$ components of velocity (below $100 \mathrm{~m}$ ). The difference between up- and down-casts was calculated at all depths for all stations, and over the whole cruise were as follows; mean $_{u}=-0.3 \pm 1.5 \mathrm{~cm} \mathrm{~s}^{-1}$, mean $_{v}=-0.2 \pm 1.3 \mathrm{~cm} \mathrm{~s}^{-1}$. In the case of good LADCP profiles, data deeper than $250 \mathrm{~m}$ were used to avoid contamination by shallow ageostrophic motions (37 of 56 station pairs); where LADCP profiles were suspect, SADCP $250-500 \mathrm{~m}$ was used (13 pairs); for shallow stations $(100-300 \mathrm{~m})$ the $\mathrm{SADCP}>100 \mathrm{~m}$ was used (4 pairs); and finally, for stations less than $100 \mathrm{~m}$ deep, the deepest good SADCP data were used (2 pairs).

[8] In order to remove the barotropic tidal components from all the ADCP velocities, tidal predictions for each profile were obtained from the Oregon State University TOPEX/Poseidon Global Inverse Solution 1/4 ${ }^{\circ}$ [Egbert et al., 1994; Egbert and Erofeeva, 2002]. Unusually high predictions of tidal currents in the shallowest water near the coast (less than $200 \mathrm{~m}$ ) raised the possibility of errors in the model predictions. The potential errors caused by limitations of bathymetry data used in the tidal model and problems with sea surface height data at the land-sea interface have been documented by Egbert and Erofeeva [2002]. To reduce errors introduced by the shallow tidal predictions we reverted to the method developed for this region by Bacon et al. [2002], in which the deepest ADCPderived velocities are taken to represent the barotropic tides at shallow stations $(<200 \mathrm{~m})$.

[9] After the on-station SADCP and LADCP velocities had been de-tided, a mean profile was calculated for each station pair, and the cross-track component obtained. The ADCP velocity profile pairs were remarkably similar, in that the vertical structure was consistent from station to station. In the case of one pair with notably different structures at either station, the deepest part of the profiles where they converged was used in the analysis. The difference between the calculated geostropic shear and the cross-track ADCP velocity profile was derived over the depth ranges describe above. The mean difference was taken to be the barotropic correction and applied to the geostrophic shear to obtain absolute velocity and volume transport. We take LADCP measurement uncertainty to be $2 \mathrm{~cm} \mathrm{~s}^{-1}$, equivalent to $\pm 1.0 \mathrm{~Sv}$ across the width and depth of the EGC in this region.

\subsection{Properties and Water Types}

[10] Potential density was used to define the upper layer of the water column that contains the water masses of the east Greenland current. The lightest water $\left(<27.70 \mathrm{~kg} \mathrm{~m}^{-3}\right)$ includes a wide range of salinity and temperature, from the cold, fresh Arctic-origin shelf water, to the warm saline North Atlantic current water. Critically for this purpose, though, it forms the boundary between the surface waters and the underlying water masses that include fresh upper Labrador Sea Water (uLSW) and the old and more saline Charlie-Gibbs Fracture Zone Water which includes Iceland Scotland Overflow Water. In the following results, all transports refer to water lighter than $27.70 \mathrm{~kg} \mathrm{~m}^{-3}$. Over the deepest part of the sections, furthest from the coast, this density class includes shallow, stratified and relatively fresh sub-Arctic surface water. There are associated transports with this water type, but since they are not part of the EGC 


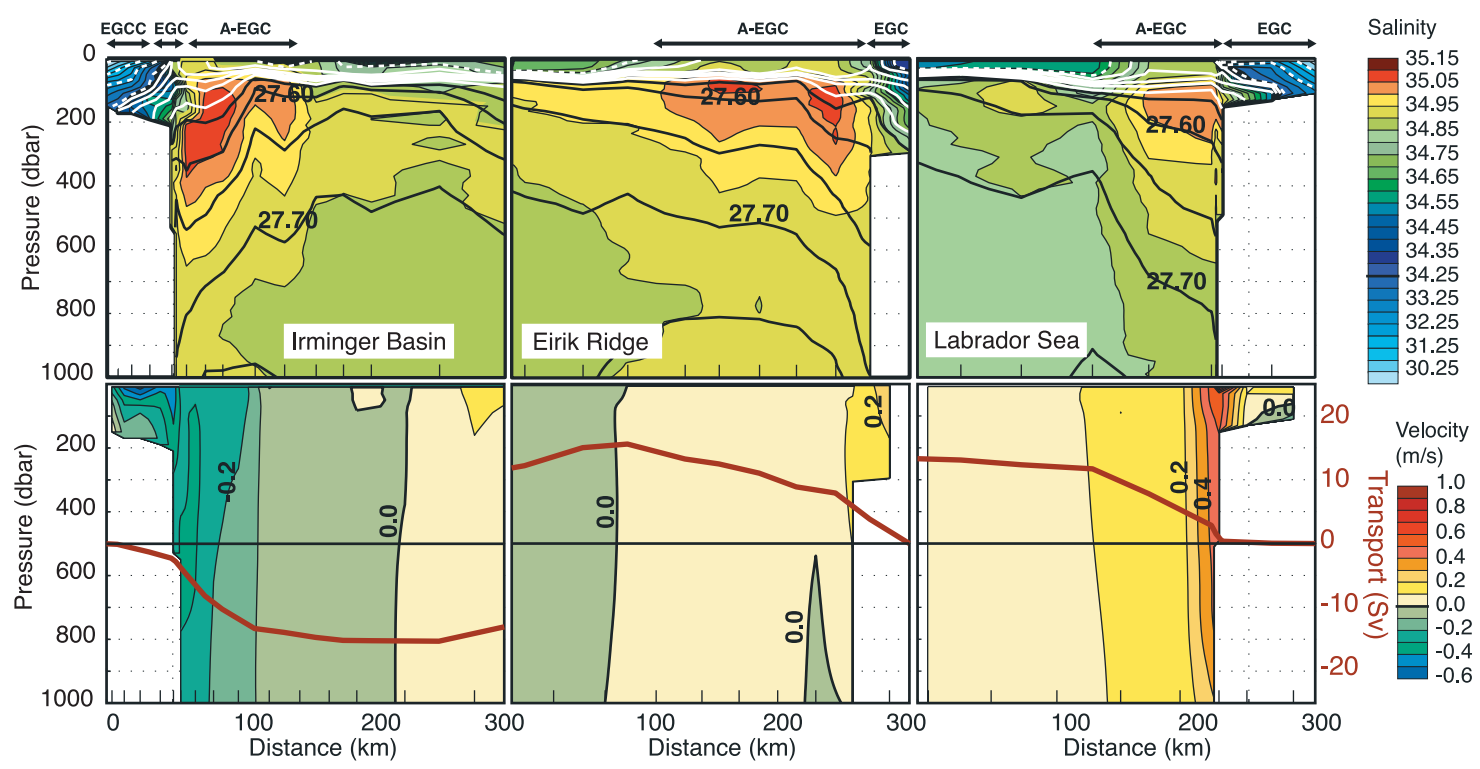

Figure 2. (top) Vertical sections of salinity with potential density and (bottom) absolute cross-track velocity with accumulated transport above $27.70 \mathrm{~kg} \mathrm{~m}^{-3}$ for the three main CTD sections. Sections are plotted against distance $(\mathrm{km})$ and are aligned approximately east-west, with Greenland on the left in the Irminger Basin and on the right in the other two sections (see Figure 1). CTD and LADCP station positions are marked by tick-marks along the horizontal axes. In Figure 2 (top) salinity is indicated by colour shading, density by contours (27.55 to 27.75 in black, 27.10 to 27.50 in solid white, and 24.00 to 27.00 in dotted white lines). Accumulated transport is calculated from zero at the coast; northwards is positive. Currents are indicated at top; EGCC is the east Greenland coastal current, EGC is the Arctic-origin east Greenland current, A-EGC is the Atlantic-origin east Greenland current. These labels are used for traceability in the Labrador Sea, though the currents become known as the west Greenland current and the Irminger Sea Water.

system they will not be referred to in the results or discussion.

\section{Results}

\subsection{East Greenland Coastal Current}

[11] The east Greenland coastal current can be seen clearly on the Irminger Basin section where it appears as the freshest, coldest and lightest water on the inner continental shelf. The salinity $(30.0-33.8)$ is much lower than the Arctic-origin waters of the EGC $(34.10-34.90)$, it is rather cooler $\left(1.5-3.8^{\circ} \mathrm{C}\right.$ compared to $\left.4.1-5.5^{\circ} \mathrm{C}\right)$ and hence it is much lighter $\left(24.0-27.0 \mathrm{~kg} \mathrm{~m}^{-3}\right.$ compared to 27.2 to $27.5 \mathrm{~kg} \mathrm{~m}^{-3}$, Figure 2). The tight slope of the isopycnals between the two water types is associated with the EGCC jet, flowing at around $40 \mathrm{~cm} \mathrm{~s}^{-1}$ and transporting $1.3 \mathrm{~Sv}$ southwards.

[12] The EGCC was not sampled at the Eirik Ridge section which did not go all the way into the coast, but was absent at the Labrador Sea section which did. The Arctic-origin EGC water on the shelf at the Eirik Ridge section provides some indication that some mixing in the Arctic-origin EGC has taken place; the stratification has increased and the slope of the isopycnals in the shoreward current jet of the EGC is less steep. The salinity however is unchanged and temperature has increased, suggesting no significant mixing with the cold fresh EGCC.

[13] At the Labrador Sea section, where the section continued into very shallow water and to the coast, the freshest water is in the range 30.50 to 34.90 with a temperature range 1.8 to $4.9^{\circ} \mathrm{C}$. This kind of water is restricted though to the two shallowest stations $(110 \mathrm{~m})$ and the very surface of the third. It appears to be a mixture of the EGCC and Arctic-origin EGC, and is associated with only one current jet moving at a maximum of $10 \mathrm{~cm} \mathrm{~s}^{-1}$. This evidence suggests that the EGCC merges with the Arctic-origin EGC as they flow around Cape Farewell, to form the west Greenland current described by Clarke [1984]. The merging of the EGC and EGCC is supported by observations from surface drifters (drogued at $15 \mathrm{~m}$ ); a very close examination of Figure 2 of Cuny et al. [2002] shows drifter trajectories following two main pathways at $60^{\circ} \mathrm{N}$ east of Cape Farewell (one on the shelf and one on the shelf break). At $45^{\circ} \mathrm{W}$ the two strands merge forming just one pathway over the shelf break.

\subsection{East Greenland Current Circulation and Transports}

[14] At the Irminger Basin section the EGC comprises two frontal jets in addition to the EGCC; the cold fresh polar jet above the shelf break $(<34.85$ and shown as light grey in Figure 1) and an offshore jet where the polar waters lie adjacent to the saline Atlantic-origin waters (34.9535. 08 and shown as dark grey in Figure 1). With the EGCC they transport $14.7 \pm 1.0 \mathrm{~Sv}$ poleward $(1.3 \mathrm{~Sv}$ in the EGCC, $6.8 \mathrm{~Sv}$ over the shelf break, and $6.5 \mathrm{~Sv}$ in the offshore current). The shelfbreak front extends to $500 \mathrm{dbar}$ against the continental slope (Figure 2), though in contrast to the fast flowing surface waters, from 200 to $500 \mathrm{dbar}$ the isopycnals are gently sloping and stratification is weak (potential density $27.55-27.65 \mathrm{~kg} \mathrm{~m}^{-3}$ ). There waters of very different salinities occupy the same density space and mixing is inevitable. The resultant changes downstream in the deeper water (300-500 dbar) are described next. 


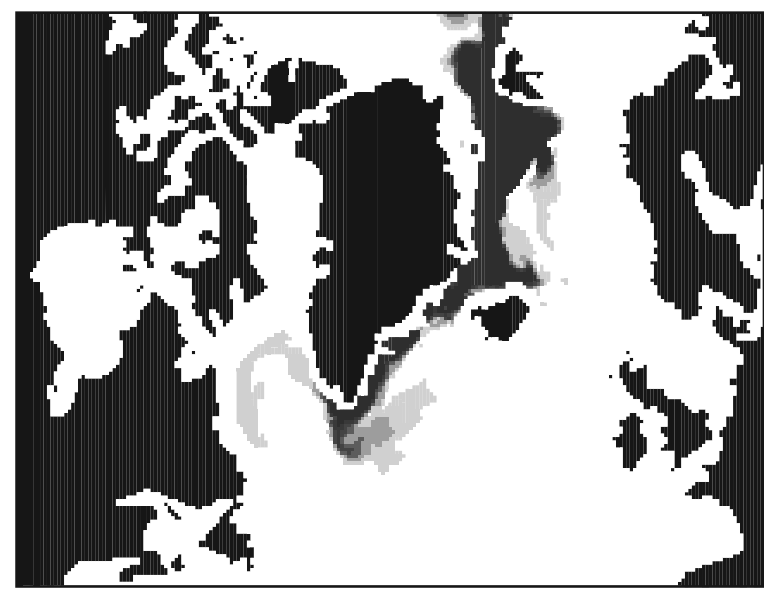

Figure 3. The evolution of a passive tracer at 315 metres in the OCCAM $1 / 4^{\circ}$ model. The tracer was initially injected as a pulse at $315 \mathrm{~m}$ (concentration $=1$ ) in a single cell in the Greenland Sea Gyre in August 1996, and monitored until December 2004. The grey scale shading indicates a concentration range of 0 (white) to $5 \times 10^{-5}$ (dark grey).

[15] Downstream at the Eirik Ridge section, the deep salinity front adjacent to the continental slope has been mixed away, and water in the range $27.60-27.65 \mathrm{~kg} \mathrm{~m}^{-3}$ has rather different properties; below the polar water it has become more saline, and below the Atlantic-origin water it has become fresher. The 35.00 isohaline has shallowed against the slope, indicating a reduced thickness of the Atlantic-origin water. Significantly, the newly mixed water is spreading along the $27.65 \mathrm{~kg} \mathrm{~m}^{-3}$ isopycnal over the Eirik Ridge (dotted pattern in Figure 1). In the process it shallows as the isopycnals dome over the upper Labrador Sea Water. The spreading of the mixed water has a large transport associated with it; $5.1 \mathrm{~Sv}$ turns southeastward over the end of Eirik Ridge and enters the interior of the subpolar gyre, one-third of the combined transport of the EGCC and EGC in the Irminger Basin, and of the EGC at the northern end of this section $(15.5 \pm 1.0 \mathrm{~Sv})$.

[16] The consequence of the mixing and southward spreading of the deeper EGC water is that the total transport of the EGC at the Labrador Sea section is significantly reduced $(11.7 \pm 1.0 \mathrm{~Sv})$. Most of the loss has occurred in the fresh water jets; the EGCC is no longer distinguishable from the polar EGC jet, and they are restricted to the shelf waters shallower than $200 \mathrm{~m}$, transporting only $2.8 \mathrm{~Sv}$ in a single current of fresher water (the west Greenland current) compared to $8.2 \mathrm{~Sv}$ in the Irminger Basin. The Atlantic water retains its core salinity of 35.05 and has a similar width, but the depth extent of the water mass is reduced from $500 \mathrm{dbar}$ in the Irminger Basin to $250 \mathrm{dbar}$ in the Labrador Sea. A small core of the new $27.65 \mathrm{~kg} \mathrm{~m}^{-3}$ water continues to flow northwards slightly offshore from the main EGC current. Figure 1 summarises the total transports.

\subsection{Modelled Retroflection of the East Greenland Current}

[17] The output from ocean general circulation models (OGCMs) can provide a large-scale context for synoptic survey results. For this analysis they provide an indication as to where the observed 5.1 Sv of EGC water that leaves the main current may flow to, given that the CTD survey is restricted in its spatial extent. A view of a tracer release experiment in the OCCAM $1 / 4^{\circ}$ OGCM [Marsh et al., 2005] supports the observations (Figure 3 ). A tracer was initially injected into the model as a pulse at $315 \mathrm{~m}$ in the Greenland Sea Gyre in August 1996 and monitored until December 2004. The initial concentration of the tracer in a single model cell was 1 . The spread of the tracer shows that water originating in the Greenland Sea flows southwards in the EGC as expected. Also as expected, some part of the EGC flows around Cape Farewell and into the margins of the Labrador Sea. However a significant proportion of the tracer follows the topography away from Cape Farewell along the Eirik Ridge, and recirculates into the interior of the Irminger Basin. This is a representation of the observed Arctic-origin EGC water mixing with the deep Atlantic-origin EGC water as detailed above. In the depth range 315-2000 $\mathrm{m}$ in the OCCAM $1 / 4^{\circ}$ model, part of the EGC retroflects back into the Irminger Basin, an effect not seen before.

\section{Conclusions}

[18] The hydrographic data show circulation consistent with existing knowledge about the surface and mid-depth circulation features: the EGC rounds the corner at Cape Farewell, transporting fresh Arctic water and saline North Atlantic water into the margins of the Labrador Sea. This analysis however provides new detail in the boundary current region where observations are sparse, since profiling floats and surface drifters quickly leave the area, the topography is shallower than float parking depths, and CTD surveys with direct current measurements are rare. Surveys in this region have historically focused on either the Irminger Basin or the Labrador Basin, and few have synoptically surveyed around the Cape to connect the two basins. Furthermore, velocities obtained from zeroreferenced baroclinic shear estimates do not show the barotropic retroflection, and also the feature is entirely subsurface, at least in the late summer months, and does not have a surface signature that satellite imagery might pick out.

[19] Specifically this analysis shows that the EGCC and Arctic waters of the EGC merge directly south of Cape Farewell where the shelf widens, and become the west Greenland current. At the same time, mixing removes the deep salinity front, creating a new water type that spreads southwards over the Eirik Ridge. This branch of the EGC, which represents one-third of the total transport of the EGC and EGCC (5.1 of 15.5 Sv at Cape Farewell), diverges from the main current into the interior of the subpolar gyre via the Eirik Ridge. This circulation pattern is consistent with the objectively mapped mean circulation of Lavender et al. [2005], derived from profiling subsurface floats, at 400, 700 and $1500 \mathrm{~m}$. Their data show separate, closed circulation cells east and west of Cape Farewell. The OCCAM model results confirm that the new branch forms a previously unknown retroflection of the EGC which dissipates through eddy activity in the centre of the Irminger Basin.

[20] The physics that control the retroflection are unclear. It seems likely that the current is topographically steered away from the Cape along the Eirik Ridge. As the bathym- 
etry deepens and the isopycnals shoal, the current will detach from the seafloor and in order to conserve potential vorticity it will turn cyclonically towards the Irminger Basin. The physics of western boundary current separation and of a well-known and well-observed retroflection system, the Agulhas current, is still a topic for debate, and these new observations alone cannot determine the causes for the EGC retroflection. The results of model studies suggests the deceleration of the flow around topography and the curvature of the coastline induce separation [Matano, 1996; Munday and Marshall, 2005], though either the inertial effects or viscous effects may dominate in different friction regimes [Dijkstra and de Ruijter, 2001]. Further analysis of the OCCAM results may begin to shed some light on the physics of the EGC retroflection.

[21] The calculated volume transport of the EGCC and EGC during the summer 2005 synoptic survey of Cape Farewell are consistent with previous estimates. Volume was conserved within the error estimates: $14.7 \pm 1.0 \mathrm{~Sv}$ in the Irminger Basin, $15.5 \pm 1.0 \mathrm{~Sv}$ at the Eirik Ridge, $11.7 \pm$ 1.0 Sv in the Labrador Sea and $5.1 \pm 0.5 \mathrm{~Sv}$ in the retroflection. There were no measurements of the EGCC at the Eirik Ridge but if a transport of $1.3 \mathrm{~Sv}$ is assumed (as measured in the Irminger Basin) the transport budget would still be approximately balanced. However it remains to be seen whether the snapshot transport values are representative of longer term mean flows. A number of current meter moorings were deployed as part of the project and results from those will be presented elsewhere.

[22] Acknowledgments. This study was funded by the CFER (Cape Farewell and Eirik Ridge: Interannual to Millennial Thermohaline Circulation Variability) project of the NERC Rapid Climate Change Directed Research Program, grant NER/T/S/2002/00453. Elaine McDonagh provided invaluable advice regarding the processing and quality assessment of LADCP data.

\section{References}

Bacon, S. (2006), RRS Discovery Cruise 298, 23 August-25 September 2005. Cape Farewell and Eirik Ridge (CFER-1), Cruise Rep. MMM, 113 pp., Natl. Oceanogr. Cent., Southampton, U.K.

Bacon, S., G. Reverdin, I. G. Rigor, and H. M. Snaith (2002), A freshwater jet on the east Greenland shelf, J. Geophys. Res., 107(C7), 3068, doi:10.1029/2001JC000935.
Clarke, R. A. (1984), Transport through the Cape Farewell-Flemish Cap section, Rapp. P.-V. Reun. Cons. Int. Explor. Mer, 185, 120-130.

Cuny, J., P. Rhines, P. P. Niiler, and S. Bacon (2002), Labrador Sea boundary currents and the fate of Irminger Sea Water, J. Phys. Oceanogr., 32, $627-647$.

Dijkstra, H. A., and W. P. M. de Ruijter (2001), On the physics of the Agulhas current: Steady retroflective regimes, J. Phys. Oceanogr., 31, $2971-2985$

Egbert, G. D., and S. Y. Erofeeva (2002), Efficient inverse modelling of barotropic ocean tides, J. Atmos. Oceanic Technol., 19, 183-204.

Egbert, G. D., A. Bennett, and M. Foreman (1994), TOPEX/Poseidon tides estimated using a global inverse model, J. Geophys. Res., 99, $24,821-24,852$.

Hansen, B., and S. Østerhus (2000), North Atlantic-Nordic Seas exchanges, Prog. Oceanogr., 45, 109-208.

Holliday, N. P., J. J. Waniek, R. Davidson, D. Wilson, L. Brown, R. Sanders, R. T. Pollard, and J. T. Allen (2006), Large-scale physical controls on phytoplankton growth in the Irminger Sea. part I: Hydrographic zones, mixing and stratification, J. Mar. Syst., 59, 201-218.

Lavender, K. L., W. B. Owens, and R. E. Davis (2005), The mid-depth circulation of the subpolar North Atlantic Ocean as measured by subsurface floats, Deep Sea Res., Part I, 52, 767-785.

Lherminier, P., H. Mercier, C. Gourcuff, M. Alvarez, S. Bacon, and C. Kermabon (2007), Transports across the 2002 Greenland-Portugal Ovide section and comparison with 1997, J. Geophys. Res., doi:10.1029/2006JC003716, in press.

Marsh, R., B. A. de Cuevas, A. Coward, A. J. G. Nurser, and S. A. Josey (2005), Water mass transformation in the North Atlantic over 1985-2002 simulated in an eddy-permitting model, Ocean Sci., 1, 127-144.

Matano, R. P. (1996), A numerical study of the Agulhas retroflection: The role of bottom topography, J. Phys. Oceanogr., 26, 2267-2279.

Munday, D. R., and J. Marshall (2005), On the separation of a barotropic western boundary current from a cape, J. Phys. Oceanogr., 35, 17261743.

Pickart, R. S., D. J. Torres, and P. S. Fratantoni (2005), The east Greenland spill jet, J. Phys. Oceanogr., 35, 1037-1053.

Rudels, B., E. Fahrbach, J. Meincke, G. Budéus, and P. Eriksson (2002), The east Greenland current and its contribution to the Denmark Strait overflow, ICES J. Mar. Sci., 59, 1133-1154.

Visbeck, M. (2002), Deep velocity profiling using Lowered Acoustic Doppler Current Profilers: Bottom track and inverse solutions, J. Atmos. Oceanic Technol., 19, 794-807.

Wilkinson, D., and S. Bacon (2005), The spatial and temporal variability of the east Greenland coastal current from historic data, Geophys. Res. Lett. 32, L24618, doi:10.1029/2005GL024232.

S. G. Alderson, S. Bacon, B. de Cuevas, N. P. Holliday, and A. Meyer, National Oceanography Centre, Southampton, University of Southampton, Waterfront Campus, Southampton SO14 3ZH, UK. (nph@noc.soton.ac.uk) 